UDC $628.5+519.6$

DOI: $10.33070 /$ etars.4.2020.06

\author{
Kolomiets O.M., Candidate of Technical Sciences \\ Institute of Coal Energy Technologies of the National Academy of Sciences of \\ Ukraine, Kyiv \\ Andriivska Str., 19, 04070 Kyiv, Ukraine, e-mail: ceti@i.kiev.ua
}

\title{
Modeling of the oxidation of nitrogen oxides by ozone
}

\begin{abstract}
A mathematical model of the process of ozone oxidation of nitrogen oxides in a chemical reactor is presented. The conformity of the model to the real process is checked by comparing the results of calculations with the data of physical experiments on a laboratory installation. The results of numerical modeling of the process in the reactor using the specified mathematical model are presented. The results of the calculations revealed the influence of the initial parameters of the process on its performance characteristics, in particular on the efficiency of conversion of nitrogen monoxide into dioxide. Based on the analysis of the calculated characteristics, the optimal operating parameters of the reactor at different modes are determined. Bibl. 5, Fig. 6, Table. 4.
\end{abstract}

Key words: nitrogen oxides, ozone, reactor, model

Along with flue gases from coal-fired thermal power plants, various harmful substances enter the environment, including nitrogen oxides $\left(\mathrm{NO}_{\mathrm{x}}\right)$. The order of the Ministry of Ecology and Natural Resources of Ukraine [1] establishes Technological standards for permissible emissions of nitrogen oxides from thermal power plants, the nominal thermal capacity of which exceeds $50 \mathrm{MW}$. There are several technologies to reduce $\mathrm{NO}_{\mathrm{x}}$ emissions. The most acceptable technology is the semi-dry method, but first it is necessary to convert nitric oxide (NO), which is sparingly soluble in water, into easily soluble compounds. Such compounds are nitrogen dioxide $\left(\mathrm{NO}_{2}\right)$, nitrogen trioxide $\left(\mathrm{NO}_{3}\right)$ and trioxide $\left(\mathrm{N}_{2} \mathrm{O}_{3}\right)$, tetroxide $\left(\mathrm{N}_{2} \mathrm{O}_{4}\right)$ and pentoxide $\left(\mathrm{N}_{2} \mathrm{O}_{5}\right)$ of diazot. Ozone $\left(\mathrm{O}_{3}\right)$ can be used for oxidation of $\mathrm{NO}$ to $\mathrm{NO}_{2}$ as a more active oxidant compared to molecular oxygen $\left(\mathrm{O}_{2}\right)$ [2].

A chemical reactor is a part of the gas path into which a certain amount of ozonated air is fed, which mixes with flue gases (model gas). Atmospheric humid air consists of $\mathrm{N}_{2}, \mathrm{O}_{2}, \mathrm{CO}_{2}$, $\mathrm{Ar}$ and $\mathrm{H}_{2} \mathrm{O}$, the content of which corresponds to the average data. After ozonation, $\mathrm{O}_{3}$ is formed in the air. The ozone content depends on the type and capacity of the ozonator and does not exceed $5 \%$ vol. A mathematical model has been developed for a more detailed study of the oxidation process. The mathematical model of the reactor takes into account the following chemical reactions [3, 4]:

$$
\begin{aligned}
& \mathrm{NO}+\mathrm{O}_{3} \rightarrow \mathrm{NO}_{2}+\mathrm{O}_{2} \\
& \mathrm{NO}_{2}+\mathrm{O}_{3} \rightarrow \mathrm{NO}_{3}+\mathrm{O}_{2} \\
& \mathrm{NO}+\mathrm{NO}_{2} \rightarrow \mathrm{N}_{2} \mathrm{O}_{3} \\
& \mathrm{NO}_{2}+\mathrm{NO}_{2} \rightarrow \mathrm{N}_{2} \mathrm{O}_{4} \\
& \mathrm{NO}_{2}+\mathrm{NO}_{3} \rightarrow \mathrm{N}_{2} \mathrm{O}_{5} \\
& \mathrm{~N}_{2} \mathrm{O}_{3} \rightarrow \mathrm{NO}+\mathrm{NO}_{2} \\
& \mathrm{~N}_{2} \mathrm{O}_{4} \rightarrow \mathrm{NO}_{2}+\mathrm{NO}_{2} \\
& \mathrm{~N}_{2} \mathrm{O}_{5} \rightarrow \mathrm{NO}_{2}+\mathrm{NO}_{3} \\
& \mathrm{NO}+\mathrm{NO}_{3} \rightarrow 2 \mathrm{NO}_{2} \\
& 2 \mathrm{NO}+\mathrm{O}_{2} \rightarrow 2 \mathrm{NO}_{2} \\
& \mathrm{~N}_{2} \mathrm{O}_{5}+\mathrm{H}_{2} \mathrm{O} \rightarrow 2 \mathrm{HNO}_{3} .
\end{aligned}
$$

Thus, the model controls the concentration of the following individual gases in the chemical reactor: $\mathrm{CO}_{2}, \mathrm{NO}_{2}, \mathrm{NO}, \mathrm{O}_{2}, \mathrm{~N}_{2}, \mathrm{Ar}, \mathrm{H}_{2} \mathrm{O}, \mathrm{O}_{3}$, $\mathrm{NO}_{3}, \mathrm{~N}_{2} \mathrm{O}_{3}, \mathrm{~N}_{2} \mathrm{O}_{4}, \mathrm{~N}_{2} \mathrm{O}_{5}, \mathrm{HNO}_{3}$.

The change in the concentration of the i-th individual gas during the residence time of the gas mixture in the chemical reactor is determined by the formula

$$
[\mathrm{X}]_{\mathrm{i}}^{\prime \prime}=[\mathrm{X}]_{\mathrm{i}}^{\prime}+\Sigma\left(\mathrm{c}_{\mathrm{i}, \mathrm{j}} \cdot \mathrm{v}_{\mathrm{j}}\right) \Delta \mathrm{t}, \mathrm{mol} / \mathrm{L}
$$

where $[\mathrm{X}]_{\mathrm{i}}^{\prime}$ and $[\mathrm{X}]_{\mathrm{i}}^{\prime \prime}$ - the concentration of the $\mathrm{i}$-th individual gas at the beginning and end of the time step; $c_{i, j}$ - stoichiometric coefficient of the $\mathrm{i}$-th individual gas in $\mathrm{j}$-th chemical reaction, positive for the reagent and negative for the product, or zero in the absence; $\mathrm{v}_{\mathrm{j}}$ - the rate of the $\mathrm{j}$-th chemical reaction; $\Delta \mathrm{t}$ - step by time, s. The rate of passage is determined for each reaction of the species 


$$
\mathrm{aA}+\mathrm{bB}->\mathrm{cC}+\mathrm{dD}
$$

where A, B, C, D - chemical substances; $\mathrm{a}, \mathrm{b}, \mathrm{c}, \mathrm{d}-$ stoichiometric coefficients.

The rate of the $\mathrm{j}$-th reaction is calculated by the formula

$$
\mathrm{v}_{\mathrm{j}}=-\mathrm{k}_{\mathrm{j}} \cdot\left[\mathrm{A}_{\mathrm{i}}\right]^{\mathrm{a}} \cdot\left[\mathrm{B}_{\mathrm{i}}\right]^{\mathrm{b}}, \mathrm{mol} /(\mathrm{L} \cdot \mathrm{s}),
$$

where $k_{j}$ - the rate constant of the $j$-th reaction, $1 / \mathrm{s}$ or $\mathrm{L} /\left(\mathrm{mol}^{\cdot \mathrm{s}}\right)$ or $\mathrm{L}^{2} /\left(\mathrm{mol}^{2} \cdot \mathrm{s}\right)$, depending on the order of the reaction; [A] and [B] - reagent concentrations, $\mathrm{mol} / \mathrm{L} ; \mathrm{a}, \mathrm{b}-$ stoichiometric coefficients; i - individual gas index; $\mathrm{j}$ - the reaction index.

The value of the rate constant of a chemical reaction at a certain temperature of gases is calculated according to the kinetic parameters [5] by the formula

$$
\mathrm{k}=\mathrm{A} \cdot(\mathrm{T} / 298)^{\mathrm{n}} \cdot \exp \left(\mathrm{E}_{\mathrm{a}} /(\mathrm{R} \cdot \mathrm{T})\right)
$$

where A - the pre-exponential coefficient; $\mathrm{n}$ - degree indicator; $\mathrm{E}_{\mathrm{a}}$ - activation energy of reagents in a certain chemical reaction, $\mathrm{J} / \mathrm{mol} ; \mathrm{R}$ - universal gas constant, $\mathrm{J} /(\mathrm{mol} \cdot \mathrm{K}) ; \mathrm{T}$ - the absolute temperature of the gases, $\mathrm{K}$.

Employees of the Department of Environmental Problems of Energy (EPE) of the Institute of Coal Energy Technologies of the National Academy of Sciences of Ukraine conducted a series of physical experiments in a laboratory to study the process of ozone oxidation of nitrogen monoxide. According to the initial parameters of physical experiments on a mathematical model of a chemical reactor, a series of calculations were performed. The technological scheme of the device is as follows. Two streams of gases are fed into the chemical reactor - model gas and ozonated moist air. Model gas is a mixture of nitric oxide and molecular nitrogen $\left(\mathrm{N}_{2}\right)$ as a carrier gas. In the gas cylinder, which is part of the experimental laboratory installation, the $\mathrm{NO}$ content according to the certificate is 1000 ppm, although in physical experiments measurements have shown that the content is 950 $\mathrm{ppm}$. The consumption of model gas is set in the range of $0.5 \ldots 4.0 \mathrm{~L} / \mathrm{min}$. During the experiments, the ozone content in the air varies in the range of $629 \ldots 908 \mathrm{ppm}$ depending on the set power of ozonator. The consumption of ozonated air is set at $0.5 \mathrm{~L} / \mathrm{min}$ and
$1.0 \mathrm{~L} / \mathrm{min}$. After mixing these two streams in a chemical reactor, the NO content in the mixture ranges from $475 \mathrm{ppm}$ to $844 \mathrm{ppm}$, and the $\mathrm{O}_{3}$ content from $94 \mathrm{ppm}$ to $454 \mathrm{ppm}$. The molar ratio of $\mathrm{O}_{3} / \mathrm{NO}$ varies in the range of $0.11 \ldots 1.37 \mathrm{~mol} / \mathrm{mol}$. The temperature of the gases during physical experiments is $12{ }^{\circ} \mathrm{C}$. In the Table 1 shows the initial content of nitrogen monoxide and ozone (inlet) and the final content of mono- and nitrogen dioxide (outlet) in the chemical reactor of the laboratory installation in various physical experiments.

Table 1. Parameters of experiments

\begin{tabular}{|c|c|c|c|c|}
\hline \multirow{2}{*}{$№$} & \multicolumn{2}{|c|}{ Inlet } & \multicolumn{2}{c|}{ Outlet } \\
\cline { 2 - 5 } & $\mathrm{NO}$ & $\mathrm{O}_{3}$ & $\mathrm{NO}$ & $\mathrm{NO}_{2}$ \\
\hline 1 & 456 & 454 & 106 & 200 \\
\hline 2 & 530 & 285 & 247 & 196 \\
\hline 3 & 655 & 213 & 434 & 195 \\
\hline 4 & 715 & 171 & 549 & 167 \\
\hline 5 & 846 & 94 & 765 & 96 \\
\hline 6 & 360 & 434 & 33 & 206 \\
\hline 7 & 435 & 317 & 155 & 184 \\
\hline 8 & 556 & 254 & 335 & 186 \\
\hline 9 & 627 & 213 & 438 & 174 \\
\hline 10 & 785 & 126 & 684 & 108 \\
\hline
\end{tabular}

In order to verify the adequacy of the mathematical model, a comparison of the results of calculations with the data of physical experiments is made. During experiments in the laboratory, the content of monoxide and nitrogen dioxide at the outlet of the chemical reactor was measured. In Fig. 1 and Fig. 2 show the difference between the values of the content of these individual gases. In the figures, the solid line indicates the points of complete coincidence of the values of the gas content, and the dotted lines indicate the deviation of the values within $\pm 10 \%$.

The calculations showed a good coincidence of the values of the concentration of nitrogen monoxide determined in numerical and physical experiments, so the points are within the deviation of $10 \%$. To assess the quality of the description of the mathematical model of chemical processes in the reactor, the coefficient of determination $\mathrm{R}^{2}$ is used. The model describes the process of conversion of nitrogen monoxide with a coefficient of determination close to 1.00 , which indicates a very high quality. 


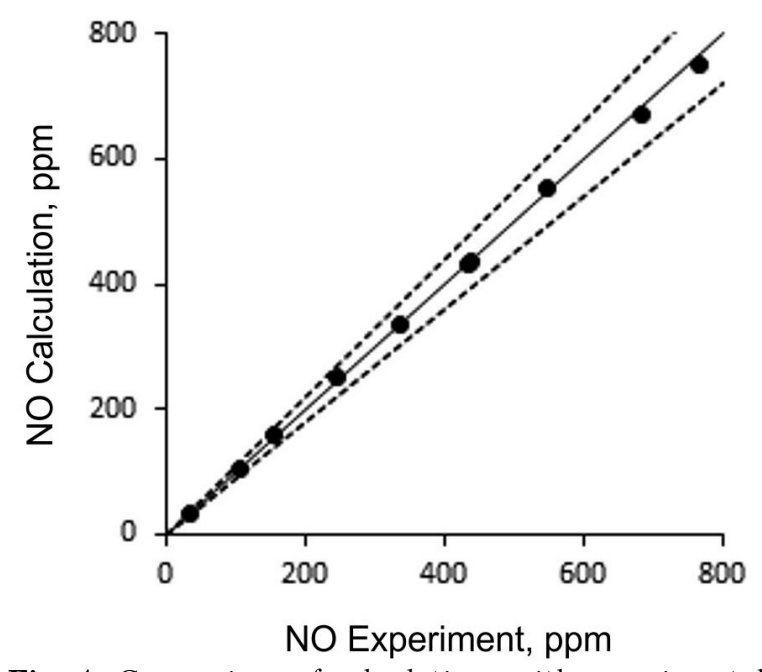

Fig. 1. Comparison of calculations with experimental

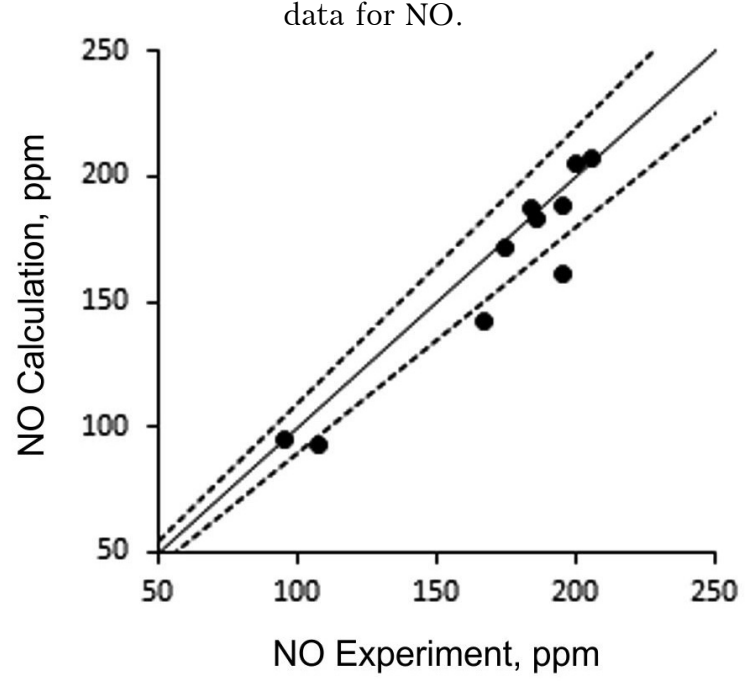

Fig. 2. Comparison of calculations with experimental data for $\mathrm{NO}_{2}$

For nitrogen dioxide, only three points are outside the "corridor" $\pm 10 \%$ at an $\mathrm{O}_{3} / \mathrm{NO}$ ratio of $0.17,0.23$ and 0.30 . The figure shows that the mathematical model also describes well the behavior of the concentration of nitrogen dioxide in a chemical reactor. The value of the coefficient of determination $\mathrm{R}^{2}$ is close to 0.95 .

According to the mathematical model, calculations of ozone oxidation of nitrogen oxides, which are part of real flue gases, were performed. The calculations were performed in the temperature range $130 \ldots 170{ }^{\circ} \mathrm{C}$, which corresponds to the real flue gas temperatures after the electrostatic precipitator with seasonal changes in atmospheric air temperature. Depending on the composition of coal and technology and mode of its combustion, the content of nitrogen oxides in the flue gases changes. It is assumed that the initial $\mathrm{NO}_{\mathrm{x}}$ content ranges from $900 \ldots 1500 \mathrm{mg} / \mathrm{Nm}^{3}$, of which 5 $\%$ is nitrogen dioxide, and $95 \%$ (in terms of $\mathrm{NO}_{2}$ ) - nitrogen monoxide. The purpose of the numerical study is to determine the amount of ozone required for the complete conversion of $\mathrm{NO}$ to $\mathrm{NO}_{2}$. The stoichiometric ratio $\mathrm{O}_{3} / \mathrm{NO}$ at the beginning of the process in a chemical reactor was chosen as an indicator. In the calculations, this figure ranged from 0.20 to 1.85 .

In the Table 2 shows the values of the rate constants of reactions (1)-(11) at a temperature of $150{ }^{\circ} \mathrm{C}$. Given the values of the constants, it is seen that the reaction (1) is likely to take place. Reaction (2) is slower because, firstly, the constant is two orders of magnitude smaller, and secondly, its rate depends on the concentration of nitrogen dioxide formed by reaction (1). Other reactions also have a low rate due to the dependence on the concentrations of the products of the first two reactions. Thus, one should expect, first of all, the conversion of nitrogen monoxide into dioxide.

Table 2. Reaction rate constants

\begin{tabular}{|r|l|l|c|}
\hline № & \multicolumn{1}{|c|}{ Chemical Reaction } & Value & Unit \\
\hline 1 & $\mathrm{NO}+\mathrm{O}_{3} \rightarrow \mathrm{NO}_{2}+\mathrm{O}_{2}$ & $4.476 \cdot 10^{7}$ & $\mathrm{~L} /(\mathrm{mol} \cdot \mathrm{s})$ \\
\hline 2 & $\mathrm{NO}_{2}+\mathrm{O}_{3} \rightarrow \mathrm{NO}_{3}+\mathrm{O}_{2}$ & $2.485 \cdot 10^{5}$ & $\mathrm{~L} /(\mathrm{mol} \cdot \mathrm{s})$ \\
\hline 3 & $\mathrm{NO}+\mathrm{NO}_{2} \rightarrow \mathrm{N}_{2} \mathrm{O}_{3}$ & $7.690 \cdot 10^{9}$ & $\mathrm{~L} /(\mathrm{mol} \cdot \mathrm{s})$ \\
\hline 4 & $\mathrm{NO}_{2}+\mathrm{NO}_{2} \rightarrow \mathrm{N}_{2} \mathrm{O}_{4}$ & $3.402 \cdot 10^{8}$ & $\mathrm{~L} /(\mathrm{mol} \cdot \mathrm{s})$ \\
\hline 5 & $\mathrm{NO}_{2}+\mathrm{NO}_{3} \rightarrow \mathrm{N}_{2} \mathrm{O}_{5}$ & $1.223 \cdot 10^{9}$ & $\mathrm{~L} /(\mathrm{mol} \cdot \mathrm{s})$ \\
\hline 6 & $\mathrm{~N}_{2} \mathrm{O}_{3} \rightarrow \mathrm{NO}+\mathrm{NO}_{2}$ & $5.252 \cdot 10^{10}$ & $1 / \mathrm{s}$ \\
\hline 7 & $\mathrm{~N}_{2} \mathrm{O}_{4} \rightarrow \mathrm{NO}_{2}+\mathrm{NO}_{2}$ & $2.704 \cdot 10^{9}$ & $1 / \mathrm{s}$ \\
\hline 8 & $\mathrm{~N}_{2} \mathrm{O}_{5} \rightarrow \mathrm{NO}_{2}+\mathrm{NO}_{3}$ & $4.063 \cdot 10^{3}$ & $1 / \mathrm{s}$ \\
\hline 9 & $\mathrm{NO}+\mathrm{NO}_{3} \rightarrow 2 \mathrm{NO}_{2}$ & $1.401 \cdot 0^{10}$ & $\mathrm{~L} /\left(\mathrm{mol}^{\prime} \mathrm{s}\right)$ \\
\hline 10 & $2 \mathrm{NO}+\mathrm{O}_{2} \rightarrow 2 \mathrm{NO}_{2}$ & $4.189 \cdot 10^{3}$ & $\mathrm{~L} /\left(\mathrm{mol}^{2} \cdot \mathrm{s}\right)$ \\
\hline 11 & $\mathrm{~N}_{2} \mathrm{O}_{5}+\mathrm{H}_{2} \mathrm{O} \rightarrow 2 \mathrm{HNO}_{3}$ & $1.510 \cdot 10^{-1}$ & $\mathrm{~L} /\left(\mathrm{mol}^{2} \mathrm{~s}\right)$ \\
\hline
\end{tabular}

Calculations of the oxidation process showed a slight dependence of the parameters at the outlet of the reactor on the temperature of the gases in the range of $130 \ldots 170{ }^{\circ} \mathrm{C}$. In the Table 3 shows the results of calculations of the main parameters at a fixed initial content of nitrogen oxides. The molar ratio $\mathrm{O}_{3} / \mathrm{NO}=1.03$. Here and further the chemical formula $\mathrm{N}_{2} \mathrm{O}_{x}$ denotes the total content of individual gases $\mathrm{N}_{2} \mathrm{O}_{3}, \mathrm{~N}_{2} \mathrm{O}_{4}$ and $\mathrm{N}_{2} \mathrm{O}_{5}$.

Table 3. The content of gases at $\mathrm{NO}_{\mathrm{x}}=1200 \mathrm{mg} / \mathrm{Nm}^{3}$

\begin{tabular}{|l|c|c|c|}
\hline $\mathrm{t},{ }^{\circ} \mathrm{C}$ & 130 & 150 & 170 \\
\hline $\mathrm{NO}_{2}, \mathrm{ppm}$ & 509 & 506 & 503 \\
\hline $\mathrm{N}_{2} \mathrm{O}_{\mathrm{x}}, \mathrm{ppm}$ & 11 & 13 & 14 \\
\hline
\end{tabular}


According to the calculations, a significant dependence of the nitrogen dioxide content at the reactor outlet on the initial content of nitrogen oxides in the range of $900 \ldots 1500 \mathrm{mg} / \mathrm{Nm}^{3}$ was revealed. In the Table 4 shows the results of calculations of the main parameters at a fixed temperature of gases. The molar ratio of $\mathrm{O}_{3} / \mathrm{NO}$ is 1.03 .

Table 4. The Gas Content at Temperature $150^{\circ} \mathrm{C}$

\begin{tabular}{|l|c|c|c|}
\hline $\mathrm{NO}_{\mathrm{x}}, \mathrm{mg} / \mathrm{Nm}^{3}$ & 900 & 1200 & 1500 \\
\hline $\mathrm{NO}_{2}, \mathrm{ppm}$ & 378 & 506 & 630 \\
\hline $\mathrm{N}_{2} \mathrm{O}_{\mathrm{x}}, \mathrm{ppm}$ & 10 & 13 & 17 \\
\hline
\end{tabular}

It should be noted that in both cases all ozone is consumed. Nitric oxide in the mixture of gases at the outlet of the chemical reactor is absent, so the efficiency of its conversion is $100 \%$.

For example, in Figure 3 shows the dependence of the content of $\mathrm{O}_{3}, \mathrm{NO}_{2}, \mathrm{NO}$ and $\mathrm{N}_{2} \mathrm{O}_{x}$ and the conversion efficiency of nitrogen monoxide at the outlet of the reactor at a flue gas temperature of $150{ }^{\circ} \mathrm{C}$ and the initial content of nitrogen oxides in them $1200 \mathrm{mg} / \mathrm{Nm}^{3}$.

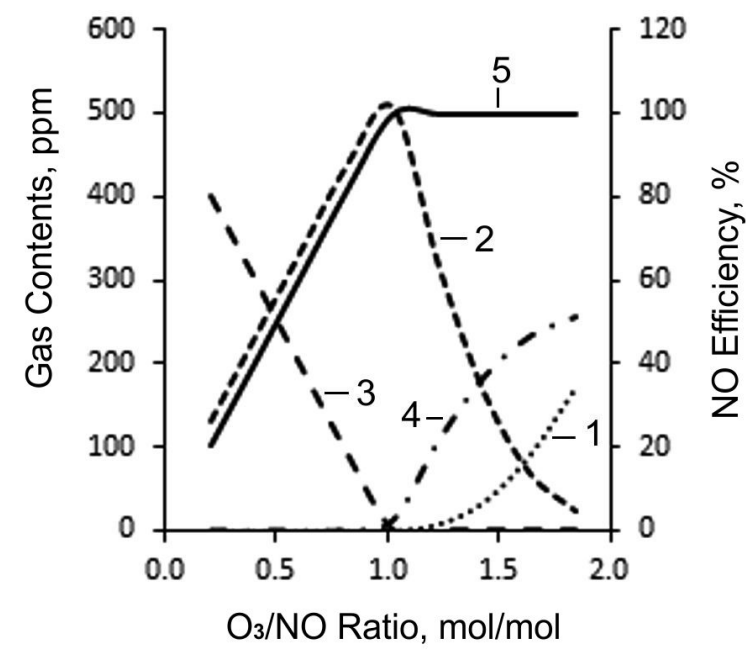

Fig. 3. The dependence of the parameters on the ratio $\mathrm{O}_{3} / \mathrm{NO}: 1-\mathrm{O}_{3} ; 2-\mathrm{NO}_{2} ; 3-\mathrm{NO}$; $4-\mathrm{N}_{2} \mathrm{O}_{\mathrm{x}} ; 5-\mathrm{NO}$ conversion efficiency.

In Figure 3 shows that the conversion efficiency of nitrogen monoxide reaches a maximum of $100 \%$ at a ratio of $\mathrm{O}_{3} / \mathrm{NO}$ equal to one. All ozone is spent on the oxidation of nitrogen monoxide to nitrogen dioxide, the concentration of which reaches a maximum, too.
When the $\mathrm{O}_{3} / \mathrm{NO}$ ratio is less than one, the NO concentration gradually decreases, and the $\mathrm{NO}_{2}$ concentration on the contrary increases. The figure shows that when the ratio of $\mathrm{O}_{3} / \mathrm{NO}$ is less than 1.0 there is an intense oxidation of $\mathrm{NO}$ to $\mathrm{NO}_{2}$.

A further increase in the ozone concentration does not lead to an increase in the $\mathrm{NO}_{2}$ content, but on the contrary its content decreases due to oxidation to nitrogen trioxide and heavier molecules are formed, namely trioxide, tetroxide and nitrous oxide. But the first two are partially or completely decomposed according to reactions (6) and (7), so most of the gas mixture is $\mathrm{N}_{2} \mathrm{O}_{5}$.

It should be noted that when $\mathrm{O}_{3} / \mathrm{NO}>1$ not all ozone is consumed. Thus, the gaseous medium becomes more aggressive towards the materials from which the gas path is made. With the subsequent use of the semi-dry method of removal of nitrogen oxides from flue gases, the release of ozone into the environment is unlikely because it is converted into molecular oxygen.

In Figures 4-6 shows the distribution of the content of the main for observation of individual gases in a chemical reactor at an initial content of nitrogen oxides of $1200 \mathrm{mg} / \mathrm{Nm}^{3}$ and a gas temperature of $150{ }^{\circ} \mathrm{C}$ with different initial ozone content. So in Figure 4 shows the dependences of the content of monoxide and nitrogen dioxide on the time spent in a chemical reactor at a given molecular ratio of $\mathrm{O}_{3} / \mathrm{NO}$ 0.21 .

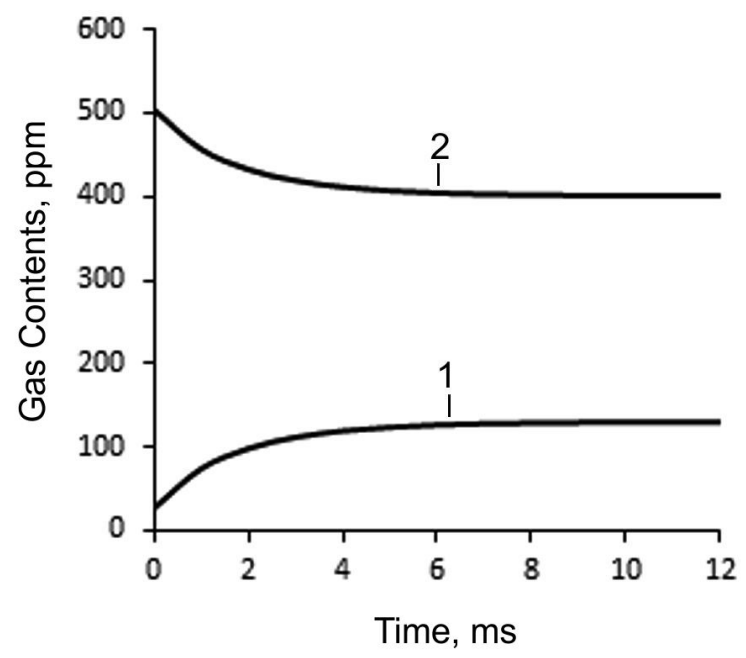

Fig. 4. The change in the content of nitrogen oxides over time at $\mathrm{O}_{3} / \mathrm{NO}<1: 1-\mathrm{NO}_{2} ; 2-\mathrm{NO}$. 
The Figure 4 shows that at the outlet of the chemical reactor, not all nitrogen monoxide is converted to dioxide due to lack of ozone. The formation of other substances occurs in very small quantities or does not occur due to low concentrations of nitrogen dioxide. With this amount, all ozone is spent only on the oxidation of $\mathrm{NO}$ to $\mathrm{NO}_{2}$. We can say that only reaction (1) takes place. The oxidation process is fast. After almost $10 \mathrm{~ms}$, the parameters go to the "shelf".

In Figure 5 shows the dependences of the content of monoxide and dioxide of nitrogen and diazotes on the time spent in a chemical reactor at a given molecular ratio of $\mathrm{O}_{3} / \mathrm{NO} 1.03$.

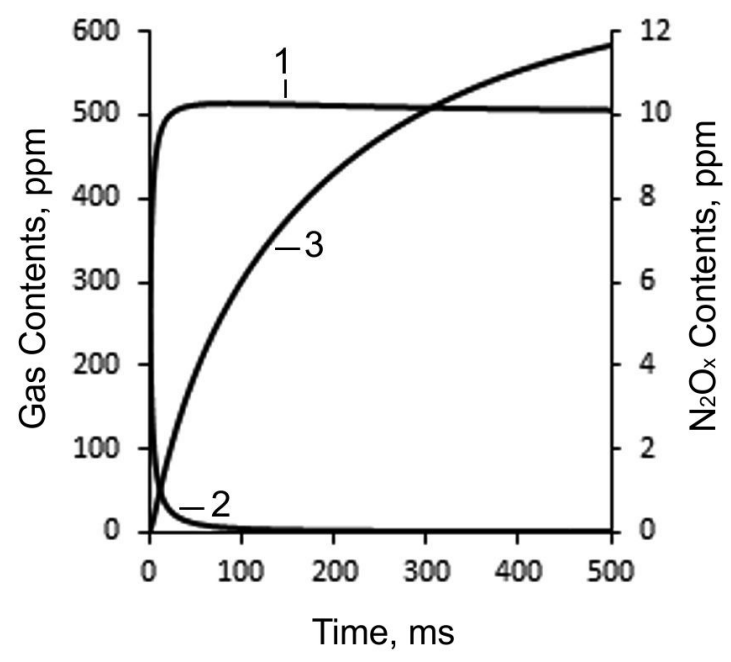

Fig. 5. The change in the content of nitrogen oxides over time at $\mathrm{O}_{3} / \mathrm{NO}>1: 1-\mathrm{NO}_{2}, 2-\mathrm{NO}$, $3-\mathrm{N}_{2} \mathrm{O}_{\mathrm{x}}$.

A slightly different picture of the behavior of the parameters is in a chemical reactor with sufficient ozone. During the first $100 \mathrm{~ms}$, all $\mathrm{NO}$ is oxidized to $\mathrm{NO}_{2}$. Moreover, part of the nitrogen dioxide is oxidized to trioxide. The formation of $\mathrm{NO}_{2}$ and $\mathrm{NO}_{3}$ opens the way to further processes. In Figure 5 shows that the concentration of $\mathrm{N}_{2} \mathrm{O}_{x}$ compounds gradually increases. These processes take 50 times longer, but they eventually stop. They stop due to the lack of ozone in the mixture of gases in the chemical reactor.

In Figure 6 shows the dependences of the content of monoxide and nitrogen dioxide and diazotes on the time spent in a chemical reactor at a given molecular ratio of $\mathrm{O}_{3} / \mathrm{NO} 1.85$.

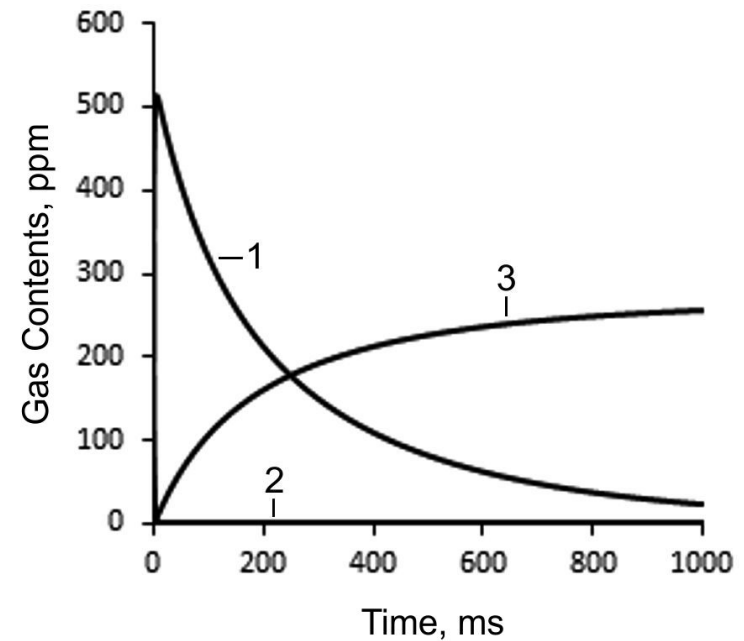

Fig. 6. The change in the content of nitrogen oxides over time at $\mathrm{O}_{3} / \mathrm{NO}>1: 1-\mathrm{NO}_{2} ; 2-\mathrm{NO}$;

$$
3-\mathrm{N}_{2} \mathrm{O}_{\mathrm{x}} \text {. }
$$

The pattern of parameter behavior in a chemical reactor changes radically with a large excess of ozone. Due to the high concentration of $\mathrm{O}_{3}$, the reaction rate is greatly increased. Thus, after $16 \mathrm{~ms}$, the concentration of nitrogen monoxide decreases by five orders of magnitude, i.e it practically disappears in the gas mixture. Moreover, the concentration of nitrogen dioxide becomes maximum. Then the same processes take place as for $\mathrm{O}_{3} / \mathrm{NO}>1$. When calculating this option, the residence time of the gas mixture in the chemical reactor is limited to $1 \mathrm{~s}$. The results show that the gases contain the required amount of ozone, so all $\mathrm{NO}_{\mathrm{x}}$ can be converted to $\mathrm{N}_{2} \mathrm{O}_{\mathrm{x}}$ in a sufficient amount of time.

\section{Conclusions}

The mathematical model better describes the conversion of nitrogen monoxide than the conversion of nitrogen dioxide. However, we can say that the model adequately describes the chemical processes in the reactor, as evidenced by a comparison of data from numerical and physical experiments. Thus, the coefficient of determination $\mathrm{R}^{2}$ for the compared parameters is not less than 0.95 .

Calculations prove that when the stoichiometric ratio of $\mathrm{O}_{3} / \mathrm{NO}$ is less than 1.0 there is an intense oxidation of $\mathrm{NO}$ to $\mathrm{NO}_{2}$. A further increase in excess ozone does not increase the $\mathrm{NO}_{2}$ content, while the NO content decreases. Calculations have shown that not only nitrogen monoxide is oxi- 
dized, but also nitrogen dioxide with the subsequent formation of heavier molecules such as nitrogen trioxide $\left(\mathrm{NO}_{3}\right)$ and trioxide $\left(\mathrm{N}_{2} \mathrm{O}_{3}\right)$, tetroxide $\left(\mathrm{N}_{2} \mathrm{O}_{4}\right)$ and pentoxide $\left(\mathrm{N}_{2} \mathrm{O}_{5}\right)$ of nitrogen.

The amount of ozone required for the complete conversion (oxidation) of nitrogen monoxide is determined by the stoichiometric ratio $\mathrm{O}_{3} / \mathrm{NO}=$ 1 and obviously depends on the initial concentration of nitrogen monoxide in the flue gases. The reaction time does not exceed $0.5 \mathrm{~s}$. A further increase in $\mathrm{O}_{3} / \mathrm{NO}$ leads to the formation of heavier compounds than nitrogen dioxide, and the reaction time does not exceed $1.0 \mathrm{~s}$. But there is no need for excess ozone $\left(\mathrm{O}_{3} / \mathrm{NO}>1\right)$ because nitrogen dioxide already dissolves well in water for further chemical binding by the semi-dry method.

In addition, there is no need to spend extra energy on ozone generation. Moreover, the environment with a lower concentration of ozone has less effect on the materials of the chemical reactor. The conversion efficiency of nitrogen monoxide increases to $100 \%$ in the range of $\mathrm{O}_{3} / \mathrm{NO}$ values to unity when all the monoxide has been oxidized.

Author expresses his sincere gratitude to colleagues from the EPE department Mezin S.V. and Yasynetsky A.A. for provided experimental data, which were used to verify the adequacy of the mathematical model of a chemical reactor for the oxidation of nitrogen oxides by ozone.

\section{References}

1. [Order of the Ministry of Ecology and Natural Resources of Ukraine from 16.02.2018 No. 62 "About modification of the order of the Ministry of Environment from 22.10.2008 No. 541"]. [Official Gazette of Ukraine]. 2018. No. 28, $290 \quad$ p. https://zakon.rada.gov.ua/laws/show /z029018\#n2/(Ukr.)

2. Kolomiiets I.I. [Review of technologies for reducing nitrogen oxide emissions at coal-fired thermal power plants]. [Ecotechnologies and Resource Saving]. $2019 . \quad$ No. 1. . 50-59. https://doi.org/10.33070/etars.1.2019.05/(Ukr.)

3. C. Sun, N. Zhao, H. Wang, and Z. Wu Simultaneous Absorption of $\mathrm{NO}_{\mathrm{x}}$ and $\mathrm{SO}_{2}$ Using Magnesia Slurry Combined with Ozone Oxidation. Energy and Fuels. 2015. Vol. 29, No. 5. P. 3276-3283. https://doi.org/10.1021/acs.energyfuels.5b00229/

4. R. Atkinson, D.L. Baulch, R.A. Cox et al. Evaluated kinetic and photochemical data for atmospheric chemistry: Volume I - gas phase reactions of $\mathrm{O}_{\mathrm{x}}, \mathrm{HO}_{\mathrm{x}}, \mathrm{NO}_{\mathrm{x}}$ and $\mathrm{SO}_{\mathrm{x}}$ species. Atmospheric Chemistry and Physics. 2004. No. 4. P. 1461-1738. https://doi.org/10.5194/acp-4-1461-2004/

5. J. A. Manion, R. E. Huie, R. D. Levin et al. NIST Chemical Kinetics Database. NIST Standard Reference Database 17, Version 7.0 (Web Version), Release 1.6.8, Data version 2015.09. National Institute of Standards and Technology, Gaithersburg, Maryland, 20899-8320. http://kinetics.nist.gov /

Received August 27, 2020

Коломієьь О.М., кандидат технічних наук Інститут вугільних енерготехнологій Національної академії наук Украӥни вул. Андріївська, 19, 04070 Київ, Україна; е-таil: сеti@i.kiеv.иа

\section{Моделювання процесу окислення оксидів азоту озоном}

Представлено математичну модель процесу окислення озоном оксидів азоту у хімічному реакторі. Відповідність моделі реальному процесу перевірена шляхом порівняння результатів розрахунків з даними фізичних експериментів на лабораторній установці. Викладено результати числового моделювання процесу у реакторі з використанням вказаної математичної моделі. За результатами виконаних розрахунків виявлено вплив вихідних параметрів процесу на його робочі характеристики, зокрема на ефективність перетворення монооксиду азоту у діоксид. На підставі аналізу розрахованих характеристик визначено оптимальні параметри роботи реактора на різних режимах. Бібл. 5, рис. 6, табл. 4.

Ключові слова: оксиди азоту, озон, реактор, модель. 


\section{Список літератури}

1. Наказ Міністерства екології та природних ресурсів України від 16.02.2018 № 62 «Про внесення змін до наказу Мінприроди від 22 жовтня 2008 року № 541». Офіційний вісник України. 2018. № 28. 290 c. - https://zakon.rada.gov.ua/laws/show/z0290$18 \#$ n2

2. Коломієць О.М. Огляд технологій зменшення викидів оксидів азоту на вугільних теплових електростанціях. Енерготехнології ресурсозбереження. 2019. № 1. С. 50-59. https://doi.org/10.33070/etars.1.2019.05

3. C. Sun, N. Zhao, H. Wang, and Z. Wu Simultaneous Absorption of $\mathrm{NO}_{\mathrm{x}}$ and $\mathrm{SO}_{2}$ Using Magnesia Slurry Combined with Ozone Oxidation. Energy and
Fuels. 2015. Vol. 29. No. 5. P. 3276-3283. https://doi.org/10.1021/acs.energyfuels.5b00229/

4. R. Atkinson, D.L. Baulch, R.A. Cox et al. Evaluated kinetic and photochemical data for atmospheric chemistry: Volume I - gas phase reactions of $\mathrm{O}_{\mathrm{x}}, \mathrm{HO}_{\mathrm{x}}, \mathrm{NO}_{\mathrm{x}}$ and $\mathrm{SO}_{\mathrm{x}}$ species. Atmospheric Chemistry and Physics. 2004. No. 4. P. 1461-1738. https://doi.org/10.5194/acp-4-1461-2004

5. J. A. Manion, R. E. Huie, R. D. Levin et al. NIST Chemical Kinetics Database, NIST Standard Reference Database 17, Version 7.0 (Web Version), Release 1.6.8, Data version 2015.09. National Institute of Standards and Technology, Gaithersburg, Maryland, 20899-8320. http:/ / kinetics.nist.gov/

Надійшла до редації 27.08.20

Коломиеи А.М., кандидат технических наук

Институт угольных энерготехнологий Национальной академии наук Украины ул. Андреевская, 19, 04070 Киев, Украина; е-таil: ceti@i.kiev.иа

\section{Моделирование процесса окисления оксидов азота озоном}

Представлено математическую модель процесса окисления озоном оксидов азота в химическом реакторе. Соответствие модели реальному процессу проверена путём сравнения результатов расчётов с данными физических экспериментов на лабораторной установке. Изложено результаты числового моделирования процесса в реакторе с применением указанной математической модели. По результатам выполненных расчётов выявлено влияние исходных параметров процесса на его рабочие характеристики, в частности на эффективность преобразования монооксида азота в диоксид. На основе анализа расчётных характеристик определено оптимальные параметры работы реактора на разных режимах. Библ. 5, рис. 6, табл. 4.

Ключевые слова: оксиды азота, озон, реактор, модель. 